Pacific Journal of Mathematics

DISJOINT MAXIMAL INVARIANT SUBSPACES 


\title{
DISJOINT MAXIMAL INVARIANT SUBSPACES
}

\author{
MALCOLM J. SHERMAN
}

\begin{abstract}
Theorem. If there exists a maximal invariant subspace of $H^{2} \mathscr{e}$ not of codimension 1 , then there exists an uncountable family $\left\{\mathscr{M}_{\alpha}\right\}$ of maximal invariant subspaces such that $\mathscr{N}_{\alpha} \cap \mathscr{N}_{\beta}=(0)$ if $\alpha \neq \beta$.
\end{abstract}

$H_{\mathscr{C}}^{2}$ is the (separable) Hilbert space of all functions $F\left(e^{i \theta}\right)$ defined on the unit circle with values in the separable infinite dimensional Hilbert space $\mathscr{H}$, and which are weakly in the Hardy class $H^{2}$. For a closed subspace of $H^{2}$, "invariant" means invariant under the right shift operator. In [5], the existence of an uncountable family of pairwise disjoint full range invariant subspaces was established, and it was remarked that while the theorem said full range invariant subspaces could be small in this sense, there was reason to believe maximal invariant subspaces (if they exist) would exhibit the same behavior. We now prove this, making essential use of a theorem of Dixmier on operator ranges. The author is grateful to Jim Williams for interpreting Dixmier's results to him.

The existence of a maximal invariant subspace of $H_{\mathscr{C}}^{2}$ not of codimension 1 is equivalent to the existence of a bounded operator on $\mathscr{\mathscr { C }}$ with no nontrivial invariant subspaces in the usual sense [3, p. 103]. Bounded one-to-one operators on $\mathscr{H}$ with disjoint ranges have disjoint Rota subspaces [4, p. 169], and these will be maximal if the operators have no invariant subspaces. It therefore suffices to show, assuming the existence of one bounded operator without invariant subspaces, that there are uncountably many such operators with disjoint ranges. If $T$ has no invariant subspaces, then $T$ has purely continuous spectrum, and since $T$ and $(T-\lambda I)$ have the same invariant subspaces, we can assume the range of $T$ (obviously dense) is not all of $\mathscr{H}$. It follows that the codimension of the range of $T$ is in fact uncountably infinite [2, Theorem 3.6, Corollary 1]. Dixmier's theorem [1, p. 84] asserts there is a continuous unitary group $\left\{U_{t}\right\}$, $-\infty<t<\infty$, such that $U_{t} T U_{t}^{-1}$ and $U_{s} T U_{s}^{-1}$ have disjoint ranges for $s \neq t$. The proof of Theorem 3.6 of [2] can be generalized to yield uncountably many disjoint operator ranges by choosing instead of the function $V$, a family $V_{t}$ defined as multiplication by 1 on $[0, t]$, and multiplication by -1 on $[t, 2 \pi]$. 


\section{REFERENCES}

1. J. Dixmier, Etude sur les varietes et les operateurs de Julia, Bull. Soc. Math. France, 77 (1949), 11-101.

2. P. Fillmore and J. Williams, On Operator Ranges, Advances in Mathematics, to appear.

3. H. Helson, Lectures on Invariant Subspaces, Academic Press, New York, 1964.

4. M. Sherman, Operators and inner functions, Pacific J. Math., 22 (1967), 159-170.

5. — Disjoint invariant subspaces, Pacific J. Math., 27 (1968), 619-620.

Received July 22, 1970. Research supported by NSF grant GP-12020

INDIANA UNIVERSITY

AND

State University of New York at Albany 


\title{
PACIFIC JOURNAL OF MATHEMATICS
}

\section{EDITORS}

\author{
H. SAMELSON \\ Stanford University \\ Stanford, California 94305 \\ C. R. HobBY \\ University of Washington \\ Seattle, Washington 98105
}

J. DugundJI

Department of Mathematics

University of Southern California

Los Angeles, California 90007

RICHARD ARENS

University of California

Los Angeles, California 90024

\section{ASSOCIATE EDITORS}
E. F. BECKENBACH
B. H. NeumanN
F. WOLF
K. YOSHIDA

\section{SUPPORTING INSTITUTIONS}

\author{
UNIVERSITY OF BRITISH COLUMBIA \\ CALIFORNIA INSTITUTE OF TECHNOLOGY \\ UNIVERSITY OF CALIFORNIA \\ MONTANA STATE UNIVERSITY \\ UNIVERSITY OF NEVADA \\ NEW MEXICO STATE UNIVERSITY \\ OREGON STATE UNIVERSITY \\ UNIVERSITY OF OREGON \\ OSAKA UNIVERSITY
}

\author{
UNIVERSITY OF SOUTHERN CALIFORNIA \\ STANFORD UNIVERSITY \\ UNIVERSITY OF TOKYO \\ UNIVERSITY OF UTAH \\ WASHINGTON STATE UNIVERSITY \\ UNIVERSITY OF WASHINGTON
AMERICAN MATHEMATICAL SOCIETY
NAVAL WEAPONS CENTER

The Supporting Institutions listed above contribute to the cost of publication of this Journal, but they are not owners or publishers and have no responsibility for its content or policies.

Mathematical papers intended for publication in the Pacific Journal of Mathematics should be in typed form or offset-reproduced, (not dittoed), double spaced with large margins. Underline Greek letters in red, German in green, and script in blue. The first paragraph or two must be capable of being used separately as a synopsis of the entire paper. The editorial "we" must not be used in the synopsis, and items of the bibliography should not be cited there unless absolutely necessary, in which case they must be identified by author and Journal, rather than by item number. Manuscripts, in duplicate if possible, may be sent to any one of the four editors. Please classify according to the scheme of Math. Rev. Index to Vol. 39. All other communications to the editors should be addressed to the managing editor, Richard Arens, University of California, Los Angeles, California, 90024.

50 reprints are provided free for each article; additional copies may be obtained at cost in multiples of 50 .

The Pacific Journal of Mathematics is published monthly. Effective with Volume 16 the price per volume (3 numbers) is $\$ 8.00$; single issues, $\$ 3.00$. Special price for current issues to individual faculty members of supporting institutions and to individual members of the American Mathematical Society: $\$ 4.00$ per volume; single issues $\$ 1.50$. Back numbers are available.

Subscriptions, orders for back numbers, and changes of address should be sent to Pacific Journal of Mathematics, 103 Highland Boulevard, Berkeley, California, 94708.

\section{PUBLISHED BY PACIFIC JOURNAL OF MATHEMATICS, A NON-PROFIT CORPORATION}

Printed at Kokusai Bunken Insatsusha (International Academic Printing Co., Ltd.), 270, 3chome Totsuka-cho, Shinjuku-ku, Tokyo 160, Japan. 


\section{Pacific Journal of Mathematics}

\section{Vol. 40, No. $2 \quad$ October, 1972}

Louis I. Alpert and L. V. Toralballa, An elementary definition of surface area in $E^{n+1}$ for smooth surfaces...........................

Eamon Boyd Barrett, A three point condition for surfaces of constant mean curvature........................................

Jan-Erik Björk, On the spectral radius formula in Banach algebras ....... 279

Peter Botta, Matrix inequalities and kernels of linear transformations . . . . 285

Bennett Eisenberg, Baxter's theorem and Varberg's conjecture ........... 291

Heinrich W. Guggenheimer, Approximation of curves .............. 301

A. Hedayat, An algebraic property of the totally symmetric loops associated with Kirkman-Steiner triple systems ....................... 305

Richard Howard Herman and Michael Charles Reed, Covariant representations of infinite tensor product algebras ................

Domingo Antonio Herrero, Analytic continuation of inner

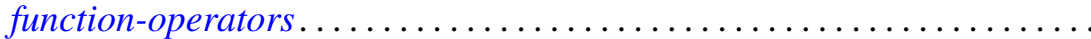

Franklin Lowenthal, Uniform finite generation of the affine group......... 341

Stephen H. McCleary, 0-primitive ordered permutation groups .......... 349

Malcolm Jay Sherman, Disjoint maximal invariant subspaces .......... 373

Mitsuru Nakai, Radon-Nikodým densities and Jacobians .............. 375

Mitsuru Nakai, Royden algebras and quasi-isometries of Riemannian manifolds. . .

Russell Daniel Rupp, Jr., A new type of variational theory sufficiency

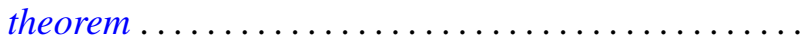

Helga Schirmer, Fixed point and coincidence sets of biconnected multifunctions on trees..........................

Murray Silver, On extremal figures admissible relative to rectangular

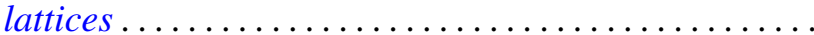

James DeWitt Stein, The open mapping theorem for spaces with unique segments ...

Arne Stray, Approximation and interpolation

Donald Curtis Taylor, A general Phillips theorem for $C^{*}$-algebras and some applications

Florian Vasilescu, On the operator $M(Y)=T Y S^{-1}$ in locally convex algebras...

Philip William Walker, Asymptotics for a class of weighted eigenvalue problems...

Kenneth S. Williams, Exponential sums over $\mathrm{GF}\left(2^{n}\right)$. 